\title{
SISTEM INFORMASI GEOGRAFIS HASIL PRODUKSI PADI DI KABUPATEN MALANG MENGGUNAKAN METODE K-MEANS CLUSTERING
}

\author{
Yongki Yudha Prasetya, Ahmad Faisol, Nurlaily Vendyansah \\ Program Studi Teknik Informatika S1, Fakultas Teknologi Industri \\ Institut Teknologi Nasional Malang, Jalan Raya Karanglo km 2 Malang, Indonesia \\ Yongkiyudhal@gmail.com
}

\begin{abstract}
ABSTRAK
Kabupaten Malang adalah daerah yang ikut serta dalam pemasok produksi padi di Negeri ini. Kabupaten Malang sendiri memiliki 33 Kecamatan yang sebagian besar penduduk nya bekerja sebagai petani padi. Dalam bertani padi ada kalanya di tiap-tiap kecamatan tersebut mengalami kenaikan ataupun penurunan produksi. Dalam pengolahan hasil produksi padi tersebut petani sendiri kadang tidak mengetahui hasil produksi padi di daerahnya. Dalam kondisi saat ini informasi sangat mendukung program ketahanan pangan dalam bidang pertanian. Pengumpulan informasi data produksi pertanian yang cepat dan akurat memudahkan dalam pengelolaan data. Dengan dibuatnya Sistem Informasi Geografis sangat membantu dalam pengolahan data produksi padi di Kabupaten Malang. Dengan adanya permasalahan tersebut maka dibuat sistem informasi geografis pemetaan hasil produksi padi di kabupaten malang dengan harapan dinas paertanian dapat mengelompokkan hasil produksi padi tiap kecamatan di kabupaten malang menggunakan metode clustering. Salah satu metode clustering yang digunakan pada sistem ini adalah metode k-means. Data yang diolah dalam penelitian ini yaitu data produksi padi tahun 2018-2020 dinas pertanian Kabupaten Malang. Sistem dibuat menggunakan website dengan framework Codeigniter, sedangkan untuk pemetaan produksi padi pada penelitian ini menggunakan Leaflet. Dari hasil pengujian sistem informasi geografis menggunakan K-Means Clustering dengan 3 cluster untuk pengelompokan hasil produksi padi di Kabupaten Malang, dengan menggunakan 99 sampel data, terdapat hasil pengelompokan sebanyak 44 (45\%) masuk dalam kategori produksi banyak, 40 (40\%) kategori produksi sedang dan 15 (15\%) produksi kurang memuaskan. Berdasarkan hasil pengujian kinerja sistem dengan membandingkan pengelompokan secara manual atau data lama dengan pengelompokan pada sistem, sistem ini cukup baik dalam mengklasifikasi warga kurang mampu dengan tingkat akurasi $100 \%$.
\end{abstract}

Kata Kunci : Sistem Informasi Geografis, Metode K-Means, Pemetaan, Produksi padi, Kabupaten Malang

\section{PENDAHULUAN}

Kabupaten Malang adalah daerah yang ikut dalam pemasok produksi padi di Negeri ini. Kabupaten Malang sendiri terdiri dari 33 Kecamatan yang sebagian besar penduduk nya bekerja sebagai petani padi. Dalam bertani padi ada kalanya di tiap kecamatan tersebut mengalami kenaikan ataupun penurunan produksi. Dalam pengolahan hasil produksi padi tersebut petani sendiri kadang tidak mengetahui hasil produksi padi di daerahnya.

Dalam kondisi saat ini informasi sangat mendukung program ketahanan pangan dalam bidang pertanian. Pengumpulan informasi data produksi pertanian yang cepat dan akurat memudahkan dalam pengelolaan data. Untuk itu diperlukan sarana pengumpul data dan informasi sistem produksi pertanian yang lebih akurat dalam waktu yang cepat. Dengan dibuatnya Sistem Informasi Geografis sangat membantu dalam pengolahan data produksi padi di Kabupaten Malang. Dengan Sistem Informasi Geografis semua petani ataupun masyarakat dapat melihat data produksi padi berupa luas tanam (ha), luas panen (ha), produktivitas (kw/ha) dan produksi (ton) dimasing-masing Kecamatan di Kabupaten Malang dan menampilkan nya di peta yang secara umum lebih memudahkan para petani untuk melihat data produksi.

Oleh karena itu, perlu adanya pengembangan sistem yang dapat membantu dalam perekapan data produksi padi dan menentukan nya dengan berbagai kategori yang telah ditentukan menggunakan metode k-means clustering dan langsung menampilkan nya di map berupa marker.

\section{TINJAUAN PUSTAKA}

2.1. Penelitian Terdahulu

Pada tahun 2017, Sibuea, M. L., \& Safta, A. melakukan penelitian dengan judul "Pemetaan Siswa Berprestasi Menggunakan Metode K-Means Clustering”. Adapun persamaan dari penelitian yaitu sama-sama menggunakan metode k-modes untuk mendapatkan hasil clustering dan untuk perhitungan jarak menggunakan manhattan distance, chbychep distance dan euclidian distance menghasilkan akurasi sebesar 67\%. (Sibuea, 2017)

Penelitian kedua tepatnya pada tahun 2016, Supuwiningsih, N. N. melakukan penelitian dengan judul "Analisis Hasil Pertanian di Kota Denpasar dengan Menggunakan Sistem Informasi Geografis. Telematika: Jurnal Informatika dan Teknologi Informasi”. Persamaan dari penelitian ini adalah sama 
sama menggunakan sistem informasi geografis sebagai media penampil data dan adapun perbedaan yakni dalam penelitian ini menggunakan software ArcViewGIS. (Supuwiningsih, 2016)

Waworuntu, M. N. V., \& Amin, M. F. ditahun 2018 melakukan penelitian dengan judul "Penerapan Metode K-Means Untuk Pemetaan Calon Penerima Jamkesda. KLIK-Kumpulan Jurnal Ilmu Komputer". Persamaan dalam penelitian ini adalah sama menggunakan metode K-means dan yang menjadi pembeda yakni dalam penelitian ini cuma mengambil 2 klaster saja. (Waworuntu \& Amin, 2018)

Pribadi, T., Irsyada, R., Audytra, H., \& Fatah, D. A. Pada tahun 2020 melakukan penelitian dengan judul "Implementasi Algoritma K-Means untuk Potensi Desa Pada Sektor Produksi Pertanian di Kabupaten Bojonegoro. Jurnal Simantec". Tujuan penelitian ini yaitu pemetaan hasil pertanian di Bojonegoro dengan data panen Padi, Jagung, Kacang Tanah, dan Kedelai. Pengelompokan potensi hasil pertanian desa sesuai adalah penggunaan Metode klasterisasi algoritma K-Means dengan perhitungan jarak menggunakan Euclidean distance sedangakan perhitungan evaluasi jarak hasil klaster menggunakan Davies-Bouldin Index (DBI). (Pribadi, Irsyada, Audytra, \& Fatah, 2020)

Hasymi, M. A., pada tahun melakukan penelitian berjudul "Sistem Informasi Geografis Pemetaan warga kurang mampu di kelurahan Karang Besuki menggunakan metode K-Means Clustering". JATI (Jurnal Mahasiswa Teknik Informatika). Tujuan penilitian ini adalah membuat sistem informasi geografis pemetaan warga kurang mampu menggunakan metode clustering serta dikombinasikan dengan QGIS 2.18. Metode clustering yang digunakan dalam sistem ini adalah metode K-Means clustering, kriteria yang digunakan pada pengelompokan data berupa umur, pekerjaan, pendidikan dan tanggungan keluarga. Persamaan dari penilitian diatas adalah sama-sama mnggunakan metode K-means clustering dan Sistem Informasi Geografis sebagai penampil datanya. (Hasymi, 2021)

Dan yang terbaru pada tahun 2021, Suryani, Tutut. Melakukan penelitian berjudul "Sistem Informasi Geografis Pemetaan kerusakan jalan di Kabupaten Malang menggunakan metode K-Means Clustering”. JATI (Jurnal Mahasiswa Teknik Informatika). Tujuan penilitian ini adalah membuat sistem informasi geografis pemetaan kerusakan jalan di Kabupaten Malang menggunakan metode clustering serta dikombinasikan dengan system informasi geografis. Metode clustering yang digunakan dalam sistem ini adalah metode K-Means clustering sedangkan system informasi yang digunakan untuk menampilkan peta menggunakan open street map kriteria yang digunakan pada pengelompokan data berupa kerusakan ringan, kerusakan sedang dan kerusakan berat. (Suryani, 2021)

\subsection{Sistem Informasi Geografis (SIG)}

Sistem informasi geografis adalah system computer yang digunakan untuk mengelola, menganalisis, dan menyebarkan informasi geografis yang berkaitan dengan tata letak keruangan dan informasi-informasi yang berhubungan dengan permukaan bumi. SIG memiliki banyak manfaat salah satunya adalah memberikan kemudahan kepada para pengguna untuk menentukan kebijaksanaan yang akan diambil. Dengan adanya system informasi geografis diharapkan dapat memudahkan pemetaan hasil produksi padi di tiap daerah. Sistem informasi georgrafis pada dasarnya memiliki pengertian, yaitu sistem informasi berbasis komputer dengan memakai data digital yang berhubungan pada letak geografis di muka bumi dan terdiri dari 3 unsur pokok yaitu sistem, informasi dan geografi.

Sistem informasi geografis yang terdiri dari sistem komputer, data geospatial, dan user. Sistem informasi geografis mempresentasikan real world (dunia nyata) di atas monitor komputer seperti lembaran peta yang dapat mempresentasikan dunia nyata diatas kertas, akan tetapi mempunyai kekuatan lebih dan fleksibilitas dari pada lembaran kertas. (P.A \& Arsandy, 2015)

\subsection{QGIS}

Quantum GIS merupakan perangkat lunak yang digunakan untuk sistem informasi geografis yang sifatnya gratis (opensource), serta penggunaannya yang cukup mudah (user friendly). Perangkat lunak ini dapat dijalankan pada berbagai jenis sistem operasi seperti Windows, Linux, Unix, Mac, Windows dan Android. Dalam QGIS memiliki banyak fungsi dan format pada vektor, raster dan basis data. (Hasymi, 2021)

\subsection{Leaflet}

Leaflet adalah Library Javascript yang bersifat Open-Source yang memungkinkan kita untuk membuat peta di website. Kita akan berinteraksi dengan Leaflet melalui API yang terdokumentasi dengan baik. Leaflet juga memiliki ukuran file yang kecil tetapi dikemas dengan fitur yang berguna dan dapat dimanfaatkan lebih jauh dengan plugin.

\subsection{Kabupaten Malang}

Kabupaten Malang adalah daerah yang ikut serta dalam pemasok produksi padi di Negeri ini. Kabupaten Malang sendiri terdiri dari 33 Kecamatan Antara lain antara lain Bululawang, Godanglegi, Tajinan, Turen, Kepanjen, Pagelaran, Pakisaji, Singosari, Lawang, Karangploso, Dau, Pakis, Dampit, Sumberpucung, Kromengan, Pagak, Kalipare, Donomulyo, Bantur, Ngajum, Gedangan, Sumbermanjing Wetan, Wagir, Wonosari, Pujon, Ngantang, Kasembon, Poncokusumo, Jabung, Wajak, Ampelgading, dan Tirtoyudoyang sebagian besar penduduk nya bekerja sebagai petani padi. Dalam bertani padi ada kalanya di tiap-tiap kecamatan 
tersebut mengalami kenaikan ataupun penurunan produksi. Dalam 3 tahun terakhir produksi padi berada pada rata - rata 500 ribu ton tiap tahun nya. Harga rata-rata gabah Kabupaten Malang cukup bagus yakni di atas harga pembelian pemerintah. Dimana gabah kering panen Rp 4.600 dan gabah kering giling $\mathrm{Rp} 5.600$ perkilogram.

\subsection{Clustering}

Clustering atau klasterisasi adalah salah satu alat bantu pada data mining yang bertujuan mengelompokkan objek-objek ke dalam clustercluster. Cluster adalah sekumpulan objek-objek data yang memiliki nilai yang hampir mirip satu sama lain dalam cluster yang sama dan data yang memiliki nilai jauh berbeda terhadap objek- objek yang berbeda cluster.

Tujuan dari klasterisasi data yaitu mengelompokkan data yang memiliki kesamaan nilai dan memisahkan data tersebut ke dalam kelompok yang berbeda untuk objek-objek yang memiliki ciri yang berbeda. Berbeda dengan klasifikasi, yang memiliki kelas yang telah didefinisikan sebelumnya. Dalam klasterisasi, klaster akan terbentuk sendiri berdasarkan ciri objek yang dimiliki dan kriteria pengelompokan yang telah ditentukan. Untuk menunjukkan klasterisasi, suatu kriteria pengelompokan haruslah ditentukan sebelumnya secara random. Perbedaan kriteria pengelompokan akan memberikan dampak perbedaan hasil akhir dari klaster yang terbentuk.

\subsection{Algoritma K-Means}

Algoritma K-Means merupakan suatu algoritma pengklasteran yang cukup sederhana yang mempartisi data kedalam beberapa clasteran K. Algoritma ini cukup mudah untuk diimplementasikan dan dijalakan, (Wu \& Kumar, 2009). Prinsip utama dari teknik ini adalah menyusun $\mathrm{K}$ buah partisi/pusat massa (centroid)/rata-rata (mean) dari sekumpulan data. Algoritma K-Means dimulai dengan pembentukan partisi klaster diawal kemudian secara iteraktif partisi claster ini diperbaiki hingga tidak terjadi perubahan yang signifikan pada partisi cluster (Sibuea, 2017)

Ada banyak metode yang dapat digunakan dalam pengelompokan / klaterisasi contohnya metode $K$-means. Pengelompokan yang dapat digunakan seperti pengelompokan non hierarki yang membagi data kedalam bentuk dua atau lebih kelompok. $K$ means merupakan metode analisis kelompok yang mengarah pada pembagian $\mathrm{N}$ objek pengamatan kedalam K kelompok (cluster) dan setiap objek pengamatan dimiliki oleh suatu kelompok dengan rata-rata (mean) terdekat. (Sibuea, 2017)

Dalam menentukan jarak terdekat antara data dengan centroid menggunakan rumus Euclidean Distance pada persamaan 2.1

$$
[(\mathrm{x}, \mathrm{y}),(\mathrm{a}, \mathrm{b})]=\sqrt{(x-a)^{2}+(y-b)^{2}}
$$

Keterangan:

- d(x,y) adalah Euclidean Distance
- (x) merupakan koordinat object

- (y) merupakan koordinat centroid

- (a) merupakan data ke 1

- (b) merupakan data ke 2

Metode K-Means Clustering hanya bisa mengolah data dalam bentuk angka, maka untuk data yang berbentuk nominal harus diinisialisasikan terlebih dahulu ke dalam bentuk angka.

Langkahnya adalah:

1. Tentukan jumlah K Cluster

2. Pilih titik secara acak sebanyak $\mathrm{K}$ buah, dimana titik ini akan menjadi pusat (centroid) dari masing masing kelompok (cluster)

3. Hitung jarak dan alokasikan masing-masing data ke centroid / rata-rata terdekat

4. Tentukan centroid baru / rata-rata dari data yang ada di masing-masing cluster

5. Kembali ke step 3, apabila masih ada data yang berpindah cluster atau ada perubahan nilai centroid. Jika tidak ada maka proses clustering dihentikan.

\section{METODE PENELITIAN}

\subsection{Analisa Kebutuhan Fungsional}

Kebutuhan fungsional menggambarkan proses kegiatan yang akan diterapkan dalam sebuah sistem. Pada Sistem Informasi Geografis Hasil Produksi padi Kabupaten Malang menggunakan metode K-Means clustering ini memiliki kebutuhan fungsional sebagai berikut

1. Sistem mampu mengelola data hasil produksi padi per kecamatan.

2. Sistem mampu melakukan proses clustering dengan menggunakan metode k-means clustering.

3. Sistem mampu menampilkan hasil dari proses clustering.

4. Sistem dapat menampilkan peta berdasarkan hasil Clustering.

\subsection{Kebutuhan Non Fungsioanl}

Adapun beberapa kebutuhan Non fungsional pada Informasi Geografis Hasil Produksi padi Kabupaten Malang menggunakan metode K-Means clustering ini memiliki kebutuhan non fungsional sebagai berikut:

1. Perangkat Lunak (Software):
a. Sublime Text
b. XAMPP
c. Web Browser
d. QGIS

2. Sistem memiliki hak akses 2 yaitu admin dan user, dalam hal ini admin adalah yang bertugas untuk mengelola data dan admin yaitu dari dinas pertanian Kabupaten Malang. User adalah masyarakat umum dan tidak perlu melakukan login untuk mengakses website.

3. Sistem memiliki fasilitas login dengan memasukkan username dan password. 


\subsection{Flowchart Sistem}

Adapun alur proses sistem dijelaskan pada Gambar 1

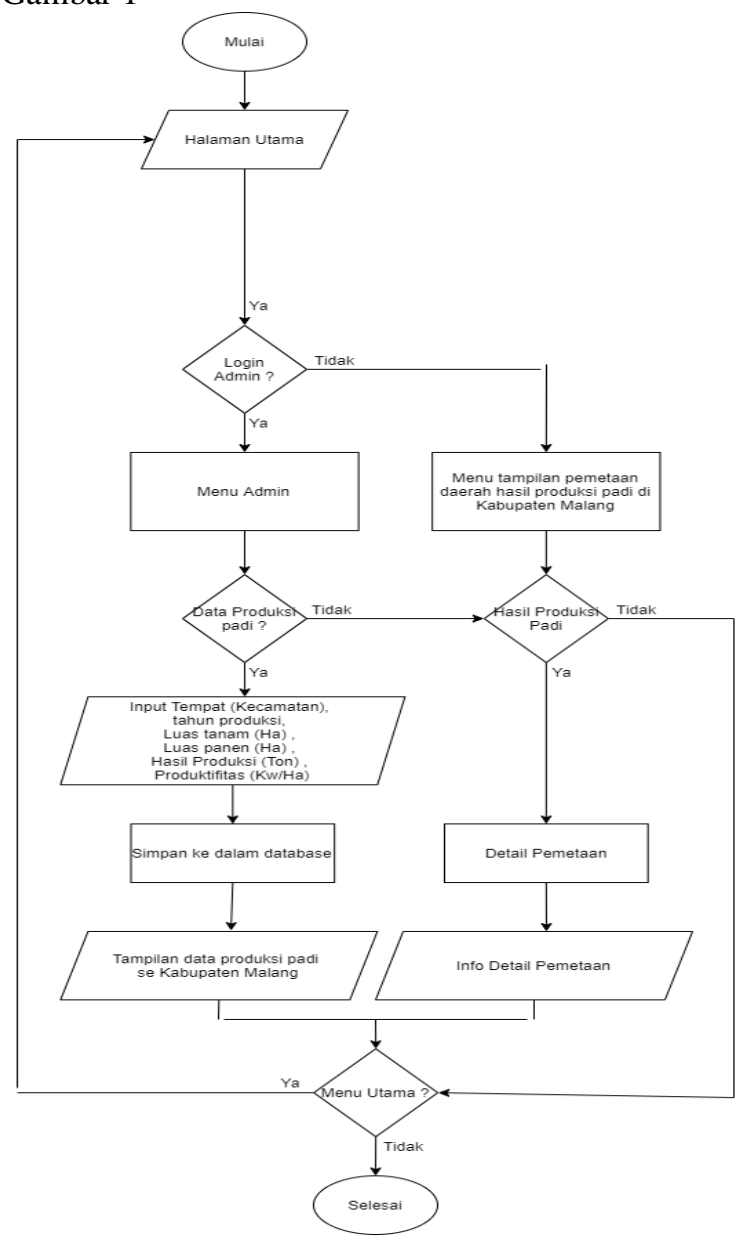

Gambar 1. Alur Proses Sistem

Alur system dimulai pada halaman utama kemudian akan ditampilkan menu untuk admin login, apabila admin berhasil login akan masuk yang dimana dapat menginputkan data berupa Input Tempat (Desa, Kecamatan), tahun produksi, Luas tanam (Ha), Luas panen (Ha), Hasil Produksi (Ton), Produktifitas $(\mathrm{Kw} / \mathrm{Ha})$. Dan apabila masuk tidak menggunakan akun administrator (user biasa) maka masuk ke tampilan pemetaan daerah produksi padi kabupaten malang disini user tidak dapat mengolah data melainkan hanya dapat melihat informasi detail produksi.

\subsection{Flowchart Metode K-Means}

Adapun alur proses flowchart metode K-Means dijelaskan pada Gambar 2, Flowchart program menjelaskan tentang alur dari metode $k$-means. Alur metode dimulai dari melakukan pre- processing data untuk membuat data mentah menjadi data berkualitas yang siap diolah atau dikelompokkan.

pre-processing data membantu didalam memperbaiki data dan mencegah kesalahan didalam data mining. Kemudian menentukan jumlah cluster dulu, setelah jumlah cluster di tentukan maka akan dilanjutkan dengan menentukan centroid, setelah menemukan centroidnya maka masuk ke proses menghitung jarak setiap data pada centroid.

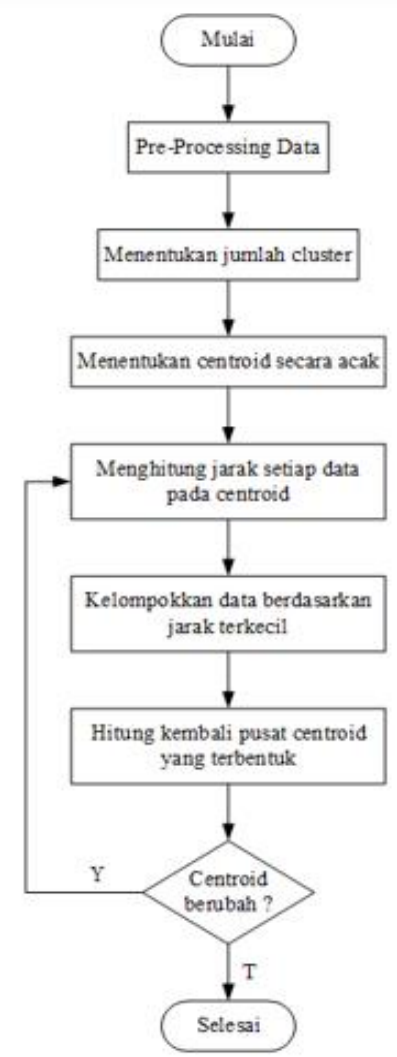

Gambar 2. Alur Flowchart metode K-Means

Untuk centroid nya sendiri dapat di tentuntakan bebas sesuai dengan nilai cluster yang akan di tentukan. Kemudian kelompokkan data berdasarkan jarak terkecil dan kelompokkan data berdasarkan clusternya.

Kemudian mencari modus atau nilai yang paling sering muncul untuk menentukan centroid baru. Centroid baru didapatkan dengan melihat data yang sering muncul modus. Dimana pada anggota kelompok tiap cluster dibandingkan nilai apa saja yang sering muncul per atribut. Jika terdapat nilai yang sama maka diambil mana yang pertama ditemui. Setelah centroid baru didapatkan proses kembali ke langkah menghitung jarak setiap data pada centroid dengan menggunakan centroid baru untuk lanjut ke iterasi selanjutnya. Proses akan berhenti jika anggota pada iterasi sebelumnya bernilai sama atau tidak ada perubahan nilai sama sekali didalam cluster nya.

\subsection{Blok Diagram Sistem}

Blok diagram adalah diagram dari sebuah sistem, di mana bagian utama atau fungsi yang diwakili oleh blok dihubungkan dengan garis, yang menunjukkan hubungan dari blok. proses kerja pada pengelompokan data hasil produksi padi di Kabupaten Malang menggunakan metode K-Means ditunjukan pada Gambar 3 


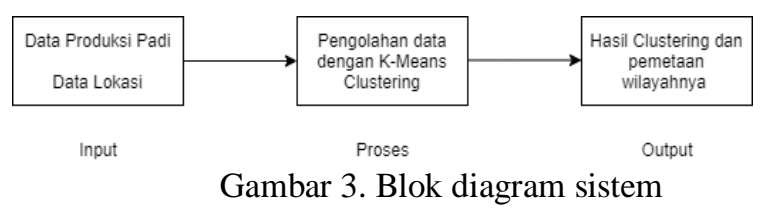

Dari blok diagram pada Gambar 3 dari inputan data yang di butuhkan adalah data produksi padi dan data lokasi buat pemetaan nya kemudian di prosesnya data tersebut diolah menggunakan metode $K$-Means clustering dan akan menghasilkan outputan berupa informasi hasil produksi padi per kecamatan di kabupaten malang dan pemetan wilayahnya.

\subsection{Perancangan Database}

1. Tabel Admin

Tabel Admin berisikan tabel untuk menyimpan data user. Tabel Admin ditunjukkan pada Tabel 1

Tabel 1. Struktur tabel admin

\begin{tabular}{|c|c|c|}
\hline Nama Field & Jenis & Keterangan \\
\hline id_user & Int (11) & Id User \\
\hline Username & Varchar (20) & Nama pengguna \\
\hline Password & Varchar(10) & Password pengguna \\
\hline Is_active & $\operatorname{Int}(2)$ & Aktivasi akun \\
\hline
\end{tabular}

\section{Tabel Produksi}

Tabel Data Produksi berisikan tabel untuk menyimpan data atribut produksi padi dan lokasi yang ada di Kabupaten Malang yang ditunjukkan pada Tabel 2

Tabel 2. Struktur tabel produksi

\begin{tabular}{|c|c|c|}
\hline Nama Field & Jenis & Keterangan \\
\hline id_produksi & Int (5) & Id User \\
\hline tahun & Varchar (5) & Tahun Produksi \\
\hline kecamatan & Varchar(20) & Nama Kecamatan \\
\hline tanam & $\operatorname{Int}(10)$ & Jumlah tanam (ha) \\
\hline panen & Int(10) & Jumlah panen (ha) \\
\hline produktivitas & float & Nilai produktivitas (kw/ha) \\
\hline produksi & Int(10) & Jumlah produksi (ton) \\
\hline longitude & Int(11) & Titik koordinat x \\
\hline latitude & $\operatorname{Int}(11)$ & Titik koordinat y \\
\hline
\end{tabular}

\section{HASIL DAN PEMBAHASAN}

4.1. Perhitungan Metode K-Means

1. Menghitung jumlah data produksi padi dari Dinas Pertanian Kabupaten Malang terdapat 99 data yang ditunjukkan pada Tabel 3

Tabel 3. Data Produksi padi Kab.Malang

\begin{tabular}{|c|c|c|c|c|c|c|}
\hline no & tahun & $\begin{array}{c}\text { kecamat } \\
\text { an }\end{array}$ & tanam & panen & $\begin{array}{c}\text { produkt } \\
\text { ivitas }\end{array}$ & $\begin{array}{c}\text { produ } \\
\text { ksi }\end{array}$ \\
\hline 1 & 2018 & $\begin{array}{c}\text { Donomu } \\
\text { lyo }\end{array}$ & 5426 & 5249 & 70.96 & 37242 \\
\hline 2 & 2018 & Kalipare & 3134 & 3028 & 70.99 & 21499 \\
\hline 3 & 2018 & Pagak & 1597 & 1598 & 64.90 & 10370 \\
\hline$:$ & & & & & & \\
\hline 99 & 2020 & $\begin{array}{c}\text { Kasemb } \\
\text { on }\end{array}$ & 1950 & 1881 & 70.27 & 13216 \\
\hline
\end{tabular}

Berdasarkan Tabel 3 dijelaskan bahwa dalam perhitungan k-means untuk produksi padi Kabupaten Malang ini menggunakan field parameter panen, produktivitas dan produksi.

2. Menentukan jumlah cluster. Data produksi dikelompokkan menjadi 3 cluster antara lain $\mathrm{C} 1=$ Banyak, $\mathrm{C} 2=$ Sedang, dan C $3=$ Kurang.

3. Menentukan centroid awal

Tabel 4. Menentukan centroid awal

\begin{tabular}{|c|c|c|c|}
\hline cluster & panen & produksi & produktivitas \\
\hline $\mathrm{C} 1$ & 1 & 1 & 1 \\
\hline $\mathrm{C} 2$ & 2 & 2 & 1 \\
\hline $\mathrm{C} 3$ & 3 & 3 & 3 \\
\hline
\end{tabular}

Selanjutnya menghitung jarak setiap data terhadap pusat cluster menggunakan perhitungan jarak euclidian menggunakan rumus persamaan (2.1).

4. Menghitung jarak euclidean. Perhitungan pada centroid tersebut dilakukan sebanyak data pada data produksi padi dengan menggunakan rumus persamaan (2.1)

Tabel 5. Jarak Euclidean

\begin{tabular}{|c|c|c|c|}
\hline Data ke- & c1 & c2 & c3 \\
\hline 1 & 0 & 1.414214 & 3.464102 \\
\hline 2 & 0 & 1.414214 & 3.464102 \\
\hline 3 & 2.44949 & 2 & 1.414214 \\
\hline$:$ & & & \\
\hline 99 & 1.414214 & 0 & 2.44949 \\
\hline
\end{tabular}

5. Mengelompokkan data sesuai cluster berdasarkan jarak terpendek. Adanya perbandingan antara data $\mathrm{c} 1$, c2, dan $\mathrm{c} 3$ dapat dilihat data mana yang paling kecil maka masuk pada cluster tersebut.

Tabel 6. Hasil Iterasi 1

\begin{tabular}{|c|c|c|c|c|}
\hline Data ke- & $\mathrm{c} 1$ & $\mathrm{c} 2$ & $\mathrm{c} 3$ & cluster \\
\hline 1 & 0 & 1.414214 & 3.464102 & 1 \\
\hline 2 & 0 & 1.414214 & 3.464102 & 1 \\
\hline 3 & 2.44949 & 2 & 1.414214 & 3 \\
\hline$:$ & & & & \\
\hline 99 & 1.414214 & 0 & 2.44949 & 2 \\
\hline
\end{tabular}

6. Menghitung centroid baru

Tabel 7. Centroid baru iterasi 2

\begin{tabular}{|c|c|c|c|}
\hline cluster & panen & produksi & produktivitas \\
\hline C1 & 1.44681 & 1.1 & 1.1 \\
\hline C2 & 2.375 & 2.3 & 1.1 \\
\hline C3 & 2.916667 & 3 & 2.4 \\
\hline
\end{tabular}

Setelah nilai dari centroid baru diketahui, langkah selanjutnya menghitung jarak data dengan centroid baru menggunakan jarak euclidien dengan rumus 2.1. Apabila cluster berubah maka perlu dilakukan iterasi lagi sampai data setiap cluster sama. 
7. Menghitungan jarak Euclidean dan hasil cluster dari iterasi 2

Tabel 8. Hasil iterasi 2

\begin{tabular}{|c|c|c|c|c|}
\hline Data ke- & $\mathrm{c} 1$ & $\mathrm{c} 2$ & $\mathrm{c} 3$ & cluster \\
\hline 1 & 0.475283 & 1.859771 & 3.058458 & 1 \\
\hline 2 & 0.475283 & 1.859771 & 3.058458 & 1 \\
\hline 3 & 2.146829 & 1.977056 & 1.42156 & 3 \\
\hline$:$ & & & & \\
\hline 99 & 1.097551 & 0.456892 & 1.920286 & 2 \\
\hline
\end{tabular}

Setelah iterasi 2 diperoleh hasil cluster yang sama dengan iterasi 3 maka perhitungan dihentikan.

\subsection{Hasil Pembentukan Cluster}

Hasil pembentukan clustering iterasi terakhir sebagai berikut:

Tabel 9. Hasil pembentukan clustering iterasi 3

\begin{tabular}{|c|l|c|c|c|}
\hline tahun & kecamatan & $\mathrm{c} 1$ & $\mathrm{c} 2$ & $\mathrm{c} 3$ \\
\hline 2018 & Donomulyo & $\sqrt{ }$ & & \\
\hline 2018 & Kalipare & $\sqrt{ }$ & & \\
\hline 2018 & Pagak & & & $\sqrt{ }$ \\
\hline 2018 & Bantur & $\sqrt{ }$ & & \\
\hline 2018 & Gedangan & & & $\sqrt{ }$ \\
\hline 2018 & Sumbermanjing & & & $\sqrt{ }$ \\
\hline 2018 & Dampit & $\sqrt{ }$ & & \\
\hline 2018 & Tirtoyudo & & & $\sqrt{ }$ \\
\hline 2018 & Ampelgading & & & $\sqrt{ }$ \\
\hline 2018 & Poncokusumo & & $\sqrt{ }$ & \\
\hline$:$ & & & & \\
\hline 2020 & Kasembon & & $\sqrt{ }$ & \\
\hline
\end{tabular}

Keterangan :

C1 : Produksi banyak

C2 : Produksi sedang

C3 : Produksi sedikit

\subsection{Halaman Utama}

Pada Halaman Utama web ditampilkan beberapa informasi mengenai tujuan dibuatnya web system informasi geografis produksi padi di Kabupaten Malang. Tampilan seperti pada gambar 4

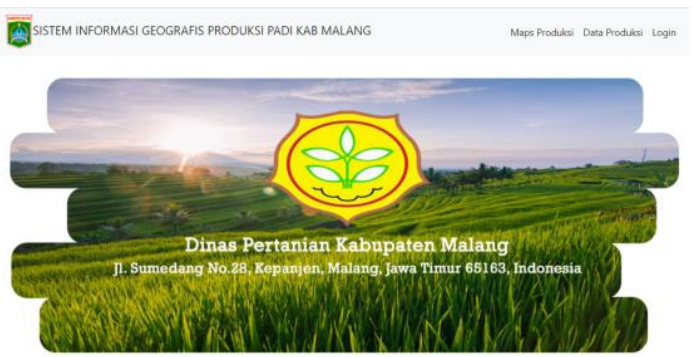

Gambar 4. Halaman Utama

\subsection{Halaman Map Produksi}

Pada Halaman Map web akan ditampilkan pemetaan hasil produksi padi di Kabupaten Malang yang ditujukan hanya untuk user biasa yang dapat melihat pemetaan nya saja tanpa bisa mengelola data. Tampilan seperti pada gambar 5

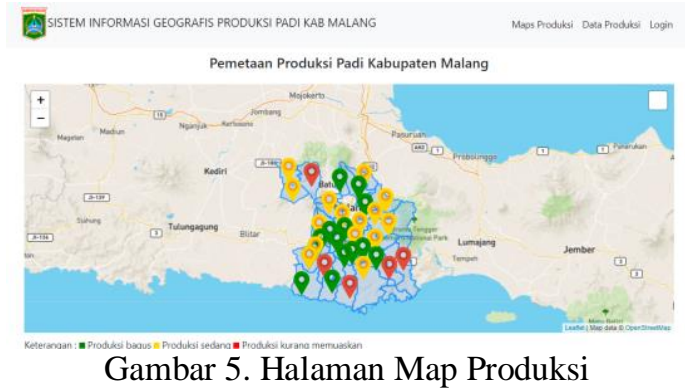

\subsection{Halaman Menu Data Produksi}

Menu data produksi sengaja di tampilkan juga di halaman utama web yang berfungsi agar user dapat melihat data hasil produksi padi berupa data table dan dapat mendownload nya menjadi file pdf. Tampilan halaman menu data produksi seperti pada gambar 6

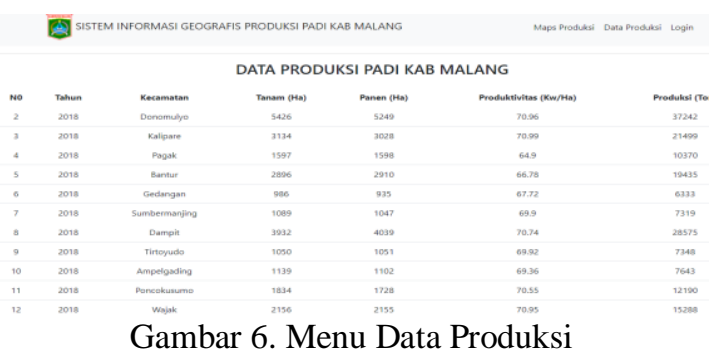

\subsection{Hasil Login}

Halaman login admin berfungsi untuk admin verifikasi akun untuk masuk kedalam halaman admin dan mengelola data admin yang berupa data user dan data produksi. Tampilan halaman login seperti pada gambar 7

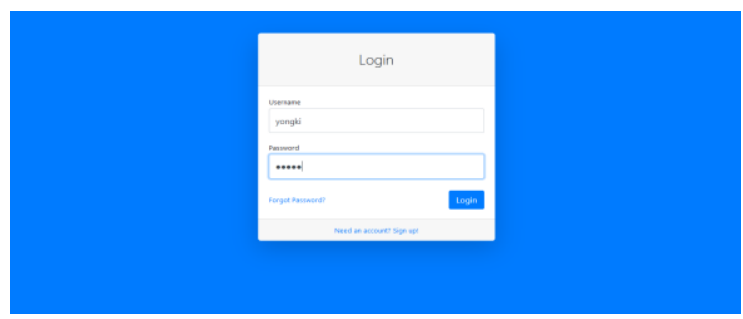

Gambar 7. Halaman Login Admin

\subsection{Hasil Admin}

Halaman Admin menampilkan berbagai macam menu yang dapat dikelola oleh admin. Tampilan halaman admin seperti pada gambar 8

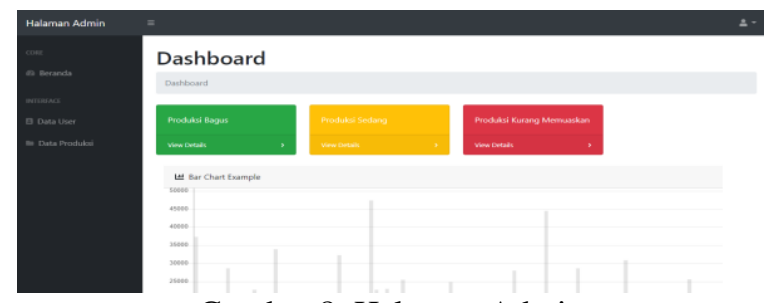

Gambar 8. Halaman Admin 


\subsection{Halaman Admin Data User}

Halaman Admin Data User menampilkan seluruh data yang ada pada tb_user, dihalaman ini terdapat 4 field table yakni (id user, username, password, is_active). Tampilan halaman admin data user seperti pada gambar 4.6

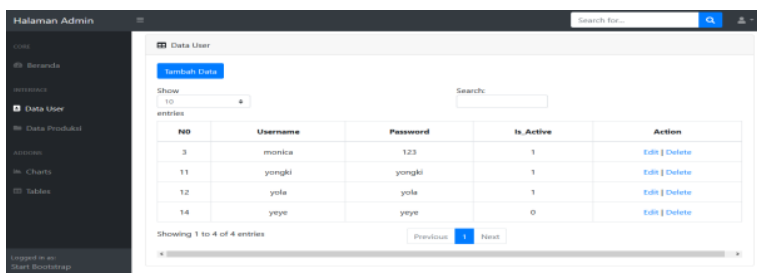

Gambar 9. Halaman Admin Data User

\subsection{Halaman Admin Data Produksi}

Halaman Admin Data Produksi menampilkan seluruh data yang ada pada tb_produksi, dihalaman ini terdapat 9 field table yakni (id produksi, kecamatan, tahun, tanam, panen, produktivitas, produksi, longitude dan latitude). Tampilan halaman admin data user seperti pada gambar 10

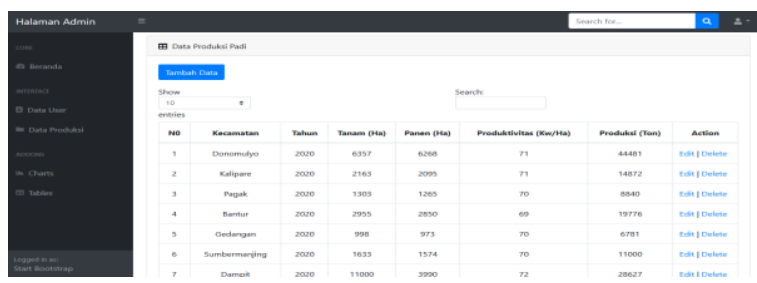

Gambar 10. Halaman Admin Data Produksi

\subsection{Pengujian Akurasi Metode}

Pengujian akurasi metode ini menggunakan sebanyak 99 data yang didapatkan dari Dinas Pertanian Kabupaten Malang dan dikelompokkan menjadi 3 cluster yaitu produksi bagus, sedang dan kurang memuaskan. Untuk mendapatkan keterangan keakuratan hasil cluster dapat dilakukan perbandingan menurut Perhitungan Manual lewat aplikasi Ms Excel dengan hasil pada aplikasi. Hasil perbandingan ditunjukkan pada Gambar 4.8 dan Gambar 4.9

\begin{tabular}{|c|c|c|c|c|l|}
\hline tahun & kecamatan & $\mathrm{c} 1$ & $\mathrm{c} 2$ & $\mathrm{c} 3$ & Ket \\
\hline 2018 & Donomulyo & $\mathrm{V}$ & & & Banyak \\
\hline 2018 & Kalipare & $\mathrm{V}$ & & & Banyak \\
\hline 2018 & Pagak & & & $\mathrm{V}$ & Kurang \\
\hline 2018 & Bantur & $\mathrm{V}$ & & & Banyak \\
\hline 2018 & Gedangan & & & $\mathrm{V}$ & Kurang \\
\hline 2018 & Sumbermanjing & & & $\mathrm{V}$ & Kurang \\
\hline 2018 & Dampit & $\mathrm{V}$ & & & Banyak \\
\hline 2018 & Tirtoyudo & & & $\mathrm{V}$ & Kurang \\
\hline 2018 & Ampelgading & & & $\mathrm{V}$ & Kurang \\
\hline 2018 & Poncokusumo & & $\mathrm{V}$ & & Sedang \\
\hline$:$ & & & & & \\
\hline 2020 & Kasembon & & $\mathrm{V}$ & & Sedang \\
\hline
\end{tabular}

Gambar 11. Hasil Cluster Manual

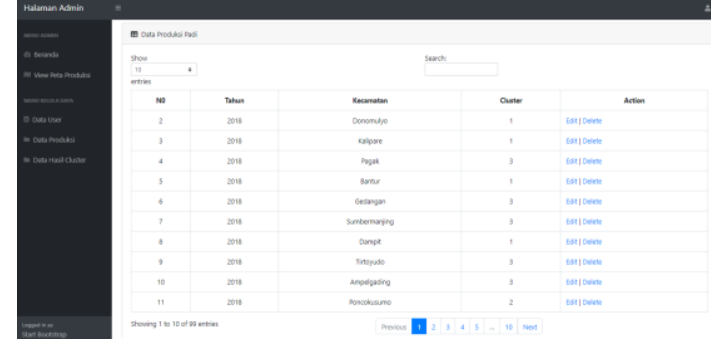

Gambar 12. Hasil Cluster program sistem

Berdasarkan perbandingan menurut dinas pertanian dengan hasil pada aplikasi, maka persentase pengujiannya hasil dari pengujian menunjukkan bahwa hasil dari perhitungan manual dibandingkan dengan hasil pada aplikasi hasilnya sama, maka dapat disimpulkan bahwa metode k-means yang diterapkan pada website ini sudah tepat.

\subsection{Pengujian Black Box}

Pengujian metode black box ini dilakukan dengan cara mengamati hasil running program untuk menguji fungsionalitas system berjalan sesuai dengan perancangan. Hasil pengujian black box dapat dilihat pada Tabel 10

Tabel 10. Pengujian Black Box

\begin{tabular}{|c|c|c|c|c|}
\hline No & $\begin{array}{c}\text { Skenario } \\
\text { Pengujian }\end{array}$ & Hasil yang diharapkan & $\begin{array}{c}\text { Hasil } \\
\text { Peng } \\
\text { uji }\end{array}$ & $\begin{array}{c}\text { Kesi } \\
\text { mpul } \\
\text { an }\end{array}$ \\
\hline 1 & $\begin{array}{l}\text { Klik Navigasi } \\
\text { Map }\end{array}$ & $\begin{array}{l}\text { Sistem akan menampilkan } \\
\text { halaman maps disertai } \\
\text { marker berwarna yang } \\
\text { mengidentifikasikan jenis } \\
\text { cluster }\end{array}$ & Sesuai & Berhasil \\
\hline 2 & $\begin{array}{l}\text { Saat login } \\
\text { menggunakan } \\
\text { username } \\
\text { belum terdaftar }\end{array}$ & $\begin{array}{l}\text { Sistem login akan menolak } \\
\text { dan menampilkan pesan } \\
\text { "username is not registered" }\end{array}$ & Sesuai & Berhasil \\
\hline 3 & $\begin{array}{l}\text { Saat login } \\
\text { menggunakan } \\
\text { akun yang } \\
\text { belum aktif }\end{array}$ & $\begin{array}{l}\text { Sistem login akan menolak } \\
\text { dan menampilkan pesan } \\
\text { "Username is not activated" }\end{array}$ & Sesuai & Berhasil \\
\hline 4 & $\begin{array}{l}\text { Halaman admin } \\
\text { data user dapat } \\
\text { menampilkan } \\
\text { data user } \\
\text { dengan show } \\
10,25,50,100 \\
\end{array}$ & $\begin{array}{l}\text { Sistem halaman user akan } \\
\text { otomatis menampilkan data } \\
\text { user dengan pilihan show } \\
10,25,50,100\end{array}$ & Sesuai & Berhasil \\
\hline 5 & $\begin{array}{l}\text { Dengan fitur } \\
\text { search Halaman } \\
\text { admin data user } \\
\text { dapat mudah } \\
\text { mencari data } \\
\text { user }\end{array}$ & $\begin{array}{l}\text { Sistem halaman user akan } \\
\text { otomatis menampilkan data } \\
\text { user dengan kata kunci nya } \\
\text { mendekati }\end{array}$ & Sesuai & Berhasil \\
\hline 6 & $\begin{array}{l}\text { Halaman } \\
\text { tambah data } \\
\text { user } \\
\text { Di kolom } \\
\text { is_active } \\
\text { menggunakan } \\
\text { combobox } \\
\text { dengan pilihan } \\
\text { hanya 1 dan } 2 \\
\end{array}$ & $\begin{array}{l}\text { Halaman tambah data user } \\
\text { memudahkan administrator } \\
\text { dalam penginputan kolom } \\
\text { is_active karena sudah } \\
\text { disediakan combobox } \\
\text { dengan pilihan } 1 \text { untuk akun } \\
\text { aktif dan pilihan } 2 \text { untuk } \\
\text { akun non aktif }\end{array}$ & Sesuai & Berhasil \\
\hline 7 & $\begin{array}{l}\text { Halaman edit } \\
\text { data user } \\
\text { Di kolom } \\
\text { is_active } \\
\text { menggunakan } \\
\text { combobox } \\
\text { dengan pilihan } \\
\text { hanya } 1 \text { dan } 2 \\
\end{array}$ & $\begin{array}{l}\text { Halaman edit data user } \\
\text { memudahkan administrator } \\
\text { dalam pengeditan kolom } \\
\text { is_active karena sudah } \\
\text { disediakan combobox } \\
\text { dengan pilihan } 1 \text { untuk akun } \\
\text { aktif dan pilihan } 2 \text { untuk } \\
\text { akun non aktif }\end{array}$ & Sesuai & Berhasil \\
\hline 8 & $\begin{array}{l}\text { Fitur hapus data } \\
\text { user }\end{array}$ & $\begin{array}{l}\text { Sistem akan melakukan } \\
\text { proses menghapus data user } \\
\text { berdasarkan id user }\end{array}$ & Sesuai & Berhasil \\
\hline
\end{tabular}




\begin{tabular}{|c|c|c|c|c|}
\hline 9 & $\begin{array}{l}\text { Halaman admin } \\
\text { data produksi } \\
\text { padi dapat } \\
\text { menampilkan } \\
\text { data user } \\
\text { dengan show } \\
10,25,50,100\end{array}$ & $\begin{array}{l}\text { Sistem halaman produksi } \\
\text { akan otomatis menampilkan } \\
\text { data produksi dengan pilihan } \\
\text { show } 10,25,50,100\end{array}$ & Sesuai & Berhasil \\
\hline 10 & $\begin{array}{l}\text { Dengan fitur } \\
\text { search halaman } \\
\text { admin data } \\
\text { produksi dapat } \\
\text { mudah mencari } \\
\text { data produksi }\end{array}$ & $\begin{array}{l}\text { Sistem halaman produksi } \\
\text { akan otomatis menampilkan } \\
\text { data produksi dengan kata } \\
\text { kunci nya mendekati }\end{array}$ & Sesuai & Berhasil \\
\hline 11 & $\begin{array}{l}\text { Halaman } \\
\text { tambah data } \\
\text { produksi } \\
\text { Di kolom } \\
\text { kecamatan } \\
\text { menggunakan } \\
\text { combobox } \\
\text { dengan pilihan } \\
\text { menurut } \\
\text { kecamatan } \\
\end{array}$ & $\begin{array}{l}\text { Halaman tambah data } \\
\text { produksi memudahkan } \\
\text { administrator dalam } \\
\text { penginputan kolom } \\
\text { longitude dan latitude } \\
\text { karena sudah disediakan } \\
\text { combobox dengan } \\
\text { dipilihnya kolom kecamatan } \\
\text { maka akan otomatis mengisi } \\
\text { nilai longitude dan latitude }\end{array}$ & Sesuai & Berhasil \\
\hline 12 & $\begin{array}{l}\text { Halaman edit } \\
\text { data produksi } \\
\text { Di kolom } \\
\text { is_active } \\
\text { menggunakan } \\
\text { combobox } \\
\text { dengan pilihan } \\
\text { menurut } \\
\text { kecamatan }\end{array}$ & $\begin{array}{l}\text { Halaman edit data produksi } \\
\text { memudahkan administrator } \\
\text { dalam penginputan kolom } \\
\text { longitude dan latitude } \\
\text { karena sudah disediakan } \\
\text { combobox dengan } \\
\text { dipilihnya kolom kecamatan } \\
\text { maka akan otomatis mengisi } \\
\text { nilai longitude dan latitude }\end{array}$ & Sesuai & Berhasil \\
\hline 13 & $\begin{array}{l}\text { Fitur hapus data } \\
\text { produksi }\end{array}$ & $\begin{array}{l}\text { Sistem akan melakukan } \\
\text { proses menghapus data } \\
\text { produksi berdasarkan id } \\
\text { produksi }\end{array}$ & Sesuai & Berhasil \\
\hline 14 & $\begin{array}{l}\text { Halaman admin } \\
\text { data cluster padi } \\
\text { dapat } \\
\text { menampilkan } \\
\text { data cluster } \\
\text { dengan show } \\
10,25,50,100\end{array}$ & $\begin{array}{l}\text { Sistem halaman cluster akan } \\
\text { otomatis menampilkan data } \\
\text { cluster dengan pilihan show } \\
10,25,50,100\end{array}$ & Sesuai & Berhasil \\
\hline 15 & $\begin{array}{l}\text { Dengan fitur } \\
\text { search halaman } \\
\text { admin data } \\
\text { cluster dapat } \\
\text { mudah mencari } \\
\text { data }\end{array}$ & $\begin{array}{l}\text { Sistem halaman cluster akan } \\
\text { otomatis menampilkan data } \\
\text { cluster dengan kata kunci } \\
\text { yang mendekati }\end{array}$ & Sesuai & Berhasil \\
\hline 16 & $\begin{array}{l}\text { Fitur edit data } \\
\text { cluster }\end{array}$ & $\begin{array}{l}\text { Sistem akan melakukan } \\
\text { proses update data cluster } \\
\text { berdasarkan id cluster }\end{array}$ & Sesuai & Berhasil \\
\hline 17 & $\begin{array}{l}\text { Fitur hapus data } \\
\text { produksi }\end{array}$ & $\begin{array}{l}\text { Sistem akan melakukan } \\
\text { proses hapus data cluster } \\
\text { berdasarkan id cluster }\end{array}$ & Sesuai & Berhasil \\
\hline 18 & $\begin{array}{l}\text { Fitur Logout } \\
\text { Admin }\end{array}$ & $\begin{array}{l}\text { Sistem melakukan proses } \\
\text { keluar dari halaman admin } \\
\text { dan akan kembali ke } \\
\text { halaman login awal } \\
\end{array}$ & Sesuai & Berhasil \\
\hline
\end{tabular}

\section{KESIMPULAN DAN SARAN}

\subsection{Kesimpulan}

Berikut ini adalah kesimpulan yang dapatkan setelah melakukan pembuatan Web Sistem Informasi Geografis hasil produksi padi di Kabupaten Malang menggunakan metode clustering K-Means Clustering adalah sebagai berikut :

1. Dari data tahun 2018 - 2020 produksi padi dengan total 99 data didapatkan perbandingan hasil clustering K-means pada program system dan data perhitungan manual menunjukkan jumlah C1 $($ Banyak $)=44$ data, $\mathrm{C} 2($ Sedang $)=$ 40, dan C3 (Kurang memuaskan) $=15$ data.

2. Hasil pengujian akurasi metode menunjukkan bahwa metode k-means yang diterapkan pada website ini sudah tepat dengan tingkat presentase kecocokannya $100 \%$.
3. Untuk produksi padi di Kabupaten Malang dari data 33 Kecamatan Mayoritas masuk ke dalam Cluster 1 yaitu (Produksi bagus)

\subsection{Saran}

Berdasakan Berdasarkan penelitian yang telah dilakukan, maka penulis dapat memberikan saran-saran untuk pengembangan selanjutnya antar lain :

1. Dalam menampilkan informasi Geografis sebaiknya lebih detail ke desa di Kabupaten Malang, Sehingga masyarakat bisa mengetahui hasil produksi padi pada tiap desa di Kabupaten Malang.

2. Penelitian selanjutkan dilakukan perbandingan hasil pengelompokan dengan perhitungan metode lain seperti K-Modes, K-NN, Single Linkage, dan metode clustering lainnya.

\section{DAFTAR PUSTAKA}

[1] Hasymi, M. A. (2021). SISTEM INFORMASI GEOGRAFIS PEMETAAN WARGA KURANG MAMPU DI KELURAHAN KARANGBESUKI MENGGUNAKAN METODE K-MEANS CLUSTERING. JATI, 05(01), 284-290.

[2] I Kadek Juni Arta, ,. N. (2020). IMPLEMENTASI APLIKASI USER MANAGEMENT HOTSPOT MIKROTIK IMPLEMENTASI APLIKASI USER MANAGEMENT HOTSPOT MIKROTIK DAN FRAMEWORK BOOTSTRAP. JURNAL RESISTOR, 66-71.

[3] Pribadi, T., Irsyada, R., Audytra, H., \& Fatah, D. A. (2020). IMPLEMENTASI ALGORITMA K-MEANS UNTUK KLASTERISASI POTENSI DESA PADA SEKTOR PRODUKSI PERTANIAN DI KABUPATEN BOJONEGORO. Jurnal Simantec, 09(01), 2028.

[4] Riri Ratna Fadila, W. A. (2019). Perancangan Perizinan Santri Menggunakan Bahasa Pemograman PHP/MySQL Di SMP Nurul Ikhlas . CSRID Journal, 84-95.

[5] Sibuea, F. L. (2017). PEMETAAN SISWA BERPRESTASI MENGGUNAKAN METODE K-MEANS CLUSTERING. JURTEKSI (Jurnal Teknologi dan Sistem Informasi), IV(1), 85 - 92 .

[6] Supuwiningsih, N. N. (2016). ANALISIS HASIL PERTANIAN DI KOTA DENPASAR DENGAN MENGGUNAKAN SISTEM INFORMASI GEOGRAFIS. TELEMATIKA, 13(02), $69-79$.

[7] Suryani, T. (2021). SISTEM INFORMASI GEOGRAFIS PEMETAAN KERUSAKAN JALAN DI KABUPATEN MALANG MENGGUNAKAN METODE K-MEANS. JATI, 05(01), 380-388.

[8] Vivi Wijaya, M. N. (2020). Sistem Informasi Penjualan Sparepart Mobil Berbasis Web Pada Sistem Informasi Penjualan Sparepart Mobil 
Berbasis Web Pada . SAINTEK (Jurnal Sains dan Teknologi), 1-4.

[9] Waworuntu, M. N., \& Amin, M. F. (2018). PENERAPAN METODE K-MEANS PEMETAAN CALON PENERIMA JAMKESDA. Kumpulan jurnaL Ilmu Komputer (KLIK), 05(02), 190-200.

[10] Wibowo, K. M., Kanedi, I., \& Jumadi, J. (2015). SISTEM INFORMASI GEOGRAFIS (SIG) MENENTUKAN LOKASI PERTAMBANGAN BATU BARA DI PROVINSI BENGKULU BERBASIS WEBSITE. Jurnal Media Infotama, 11(01), 5160. 